\title{
Pengaruh Time Budget Pressure Terhadap Perilaku Disfungsional Auditor dengan Mediasi Skeptisisme Profesional di KAP Provinsi Bali
}

\author{
Ida Ayu Made Widiantari ${ }^{1}$ \\ Ida Bagus Putra Astika ${ }^{2}$
}

\author{
${ }^{1}$ Fakultas Ekonomi dan Bisnis Universitas Udayana (Unud), Bali, Indonesia \\ email: dayuwidia96@gmail.com /Telp : 081805346902 \\ ${ }^{2}$ Fakultas Ekonomi dan Bisnis Universitas Udayana (Unud), Bali, Indonesia
}

\begin{abstract}
ABSTRAK
Adanya ketidaksesuaian antara waktu yang tersedia dengan waktu yang dibutuhkan untuk menyelesaikan tugas audit dapat berpengaruh terhadap professional kerja seorang auditor.Penelitian ini dilakukan di seluruh kantor Kantor Akuntan Publik di Bali sebanyak sembilan kantor yang terdapat pada Wilayah Bali tahun 2017 dengan menjadikan auditor sebanyak 70 orang sebagai sampel dengan metode sample jenuh. Pengumpulan data dilakukan dengan menyebarkan kuesioner dengan 52 responden yang kembali dan layak digunakan sedangkan 21 digugurkan. Teknik analisis yang digunakan adalah teknik path analisis. Berdasarkan hasil analisis, variabel time budget pressure berpengaruh positif signifikan terhadap perilaku disfungsional auditor pada Kantor Akuntan Publik di Bali. Time budget pressure berpengaruh negatif terhadap skeptisisme profesional auditor pada Kantor Akuntan Publik di Bali. Skeptisisme profesional auditor berpengaruh negatif terhadap perilaku disfungsional auditor pada Kantor Akuntan Publik di Bali. Skeptisisme profesional auditor memediasi pengaruh positif time budget pressure terhadap perilaku disfungsional auditor pada Kantor Akuntan Publik di Bali.
\end{abstract}

Kata kunci: time budget pressure, skeptisisme profesional auditor, perilaku disfungsional auditor.

\begin{abstract}
This research is done in all offices of Public Accounting Firm in Bali as many as nine offices located in the Region of Bali in 2017 by making auditors as much as 70 people as sample with saturated sample method. Data collection was done by distributing questionnaires with 52 respondents who returned and deserve to be used while 21 were aborted. Analytical technique used is path analysis technique. Based on the analysis, time budget pressure variable has a significant positive effect on dysfunctional behavior of auditors at Public Accounting Firm in Bali. Time budget pressure negatively affects the skepticism of auditor professionals at Public Accounting Firm in Bali. Skepticism of professional auditors negatively affects the dysfunctional behavior of auditors at Public Accounting Firm in Bali. Professional auditor skepticism mediates the positive influence of time budget pressure on dysfunctional behavior of auditors at Public Accounting Firm in Bali.

Keywords: time budget pressure, professional skepticism of auditors, dysfunctional behavior of auditors.
\end{abstract}

\section{PENDAHULUAN}

Profesi akuntan publik merupakan profesi kepercayaan masyarakat yang mengharapkan penilaian yang bebas dan tidak memihak dalam melaksanakan audit terhadap informasi yang disajikan oleh manajemen perusahaan dalam 
Ida Ayu Made Widiantari dan Ida Bagus Putra Astika. Pengaruh...

laporan keuangan (Mulyadi, 2002:2). Audit merupakan proses yang sistematik, independen dan terdokumentasi untuk memperoleh bukti audit dan mengevaluasinya secara objektif untuk menentukan sampai sejauh mana kriteria audit dipenuhi (Desi dan Armanto, 2015). Oleh karena itu, seorang auditor harus membuat laporan hasil temuan yang transparan, akurat, tepat waktu, dan tidak menyimpang dari standar akuntansi keuangan atau prinsip akuntansi yang diterima umum (Fikri, 2015). Belakangan ini profesi akuntan publik menjadi sorotan banyak pihak. Sorotan tajam diberikan karena akuntan publik dianggap memiliki kontribusi dalam banyak kasus kebangkrutan perusahaan. Profesionalisme akuntan seolah dijadikan kambing hitam dan harus memikul tanggung jawab pihak lain yang seharusnya bertanggungjawab atas kegagalan itu (Andreas, 2016).

Auditing adalah pengumpulan dan evaluasi bukti tentang informasi untuk menentukan dan melaporkan derajat kesesuaian antara informasi itu dan kriteria yang telah ditetapkan (Anis, 2014). Tujuan akhir dari proses auditing ini adalah menghasilkan laporan audit, laporan audit inilah yang digunakan oleh auditor untuk menyampaikan pernyataan atau pendapatnya kepada para pemakai laporan keuangan, sehingga bisa dijadikan acuan bagi pemakai laporan keuangan (Surtikanti dan Lena, 2015). Kualitas pekerjaan auditor berhubungan dengan kualifikasi keahlian, ketepatan waktu penyelesaian pekerjaan, kecukupan bukti pemeriksaan, agar tujuan tersebut tercapai maka perilaku disfungsional seorang akuntan publik dalam menjalankan profesinya harus mengacu pada standar yang 
telah ditetapkan yaitu Standar Profesional Akuntan Publik (SPAP) dari Ikatan Akuntan Publik Indonesia (IAPI).

Ada kalanya opini audit kurang mendapat respon yang positif dikarenakan adanya kemungkinan terjadinya perilaku disfungsional oleh seorang auditor dalam proses audit (Donnelly et al., 2003) dalam Mahatma dan Suaryana (2016). Sujana dan Sawarjuwono (2006) dalam Mahatma dan Suaryana (2016) mengungkapkan bahwa perilaku disfungsional merupakan perilaku auditor yang menyimpang, dapat diartikan secara langsung maupun tidak langsung mengurangi hasil temuan audit. Medhat \& Gary (2015) menambahkan perilaku disfungsional audit disini adalah bentuk manipulasi, kecurangan ataupun penyimpangan terhadap standar audit.

Perilaku disfungsional auditor dalam pelaksanaan program audit merupakan faktor penting yang berpengaruh terhadap hasil temuan audit yang dihasilkan Kantor Akuntan Publik (KAP) (Mahatma \& Suaryana, 2012). Perilaku audit disfungsional adalah setiap tindakan yang dilakukan auditor dalam pelaksanaan audit yang dapat mereduksi atau menurunkan hasil temuan audit secara langsung maupun tidak langsung (Kelley dan Margheim, 1990; dalam Mahatma \& Suaryana, 2012). Dalam literatur, tindakan - tindakan yang dilakukan auditor dalam pelaksanaan audit yang dapat mereduksi hasil temuan audit secara langsung disebut sebagai perilaku disfungsional audit, yang dapat mereduksi hasil temuan audit secara tidak langsung, seperti penghentian premature, prosedur audit, review yang dangkal terhadap dokumen klien, bias sampel, tidak memperluas skor pengujian ketika tidak terdeteksi ketidak beresan dan tidak 
Ida Ayu Made Widiantari dan Ida Bagus Putra Astika. Pengaruh...

meneliti kesesuaian perilaku akuntansi yang diterapkan klien (Dina dan Erna, 2013).

Ongky (2012) menyatakan terjadinya perilaku disfungsional auditor terhadap kewajaran sebuah laporan keuangan, disebabkan oleh banyak faktor, salah satunya adalah time budget pressure. Variabel time budget pressure diambil karena tekanan anggaran waktu audit dapat menyebabkan auditor merasa tertekan dalam melaksanakan prosedur audit karena ketidakseisuaian antara waktu yang tersedia dengan waktu yang dibutuhkan untuk menyelesaikan tugas audit, dan selanjutnya kondisi tersebut dapat memotivasi auditor melakukan tindakan audit disfungsional (Kelley dan Seiler, 1982; Cook dan Kelley,1988). Time budget pressure adalah keadaan yang menunjukkan auditor dituntut untuk melakukan efisiensi terhadap anggaran waktu yang telah disusun atau terdapat pembahasan waktu anggaran yang sangat ketat dan kaku (Halil et al., 2010). Time budget pressure yang ketat sering menyebabkan auditor meninggalkan bagian program audit penting dan akibatnya menyebabkan penurunan hasil temuan audit (Muslim, 2016). Situasi di mana auditor di batasi pada time budget pressure dan cenderung kaku akan memotivasi auditor untuk melewati atau mengabaikan beberapa prosedur audit sehingga penugasannya dapat selesai pada waktunya tanpa memperhatikan hasil temuan audit. Perilaku pengurangan kualitas audit seperti penghentian premature (premature sign off) atas prosedur audit sering dikaitkan dengan anggaran waktu audit dan sistem pengendalian secara keseluruhan (Rabih et al., 2016). Tindakan penghentian premature ini berkaitan dengan penghentian terhadap prosedur audit yang disyaratkan, tidak melakukan pekerjaan secara 
lengkap dan mengabaikan prosedur audit tetapi auditor berani mengungkapkan opini atas laporan keuangan yang diauditnya. Probabilitas auditor dalam membuat keputusan dan opini yang salah akan semakin tinggi, jika salah satu atau beberapa langkah dalam prosedur audit diabaikan (Ratna et al., 2016). Perilaku seperti ini tentu mempengaruhi terjadinya perilaku disfungsional auditor dalam melaksanakan tugasnya sebagai pihak yang independen (Indri dan Sukartha, 2017).

Marisa (2016) menyatakan bahwa time budget pressure dapat mempengaruhi terjadinya perilaku disfungsional auditor. Shaun et al. (2008) menyatakan hal yang sama dimana time budget pressure secara positif mempengaruhi tindakan perilaku disfungsional auditor. Desi dan Armanto (2015) dalam penelitiannya membuktikan ada pengaruh positif time budget pressure terhadap perilaku disfungsional auditor dalam melaksanakan audit perusahaan.

Begitu pentingnya hasil temuan audit yang diberikan oleh auditor bagi sebuah perusahaan, maka seorang auditor dituntut untuk menghindari terjadinya perilaku disfungsional, oleh karena itu seorang auditor harus melaksanakan sikap skeptisisme profesionalnya sehingga auditor dapat menggunakan kemahiran profesionalnya dengan cermat dan seksama, karena kemahiran profesional seorang auditor mempengaruhi ketepatan opini yang diberikannya untuk menghasilkan temuan audit yang berkualitas (Pretty, 2015). Sehingga tujuan auditor untuk memperoleh bukti kompeten yang cukup dan memberikan basis yang memadai dalam merumuskan pendapat dapat tercapai dengan baik. 
Ida Ayu Made Widiantari dan Ida Bagus Putra Astika. Pengaruh...

Audit atas laporan keuangan berdasarkan atas standar auditing yang ditetapkan Ikatan Akuntan Indonesia harus direncanakan dan dilaksanakan dengan sikap skeptisisme profesional Standar Profesional Akuntan Publik (SPAP, 2001). Skeptisisme profesional dapat dilatih oleh auditor dalam melaksanakan tugas audit dan dalam mengumpulkan bukti yang cukup untuk mendukung atau membuktikan asersi manajemen. Sikap skeptis dari auditor ini diharapkan dapat mencerminkan kemahiran profesional dari seorang auditor sehingga mengurangi terjadinya perilaku disfungsional auditor. Auditor diharapkan dapat melaksanakan tugasnya sesuai standar yang telah ditetapkan dengan sikap skeptisisme profesional, menjunjung tinggi kaidah dan norma agar hasil temuan audit dan citra profesi auditor tetap terjaga (Halil et al., 2010). Kemahiran profesional auditor akan sangat mempengaruhi ketepatan pemberian opini oleh auditor yang mewujudkan hasil temuan audit yang berkualitas, sehingga secara tidak langsung skeptisisme profesional auditor atau memediasi hubungan time budget pressure terhadap perilaku disfungsional auditor.

Beberapa penelitian seperti Indri dan Sukartha (2017) menyatakan bahwa skeptisisme profesional berpengaruh terhadap perilaku disfungsional auditor. Halil et al. (2010) menyatakan bahwa skeptisisme profesional secara tidak langsung mempengaruhi perilaku disfungsional auditor. Medhat \& Gary (2015) menyatakan hal yang sama dimana skeptisisme profesional memediasi pengaruh time budget pressure secara positif pada perilaku disfungsional auditor. Nor et al. (2013) dalam penelitiannya membuktikan ada pengaruh positif time budget 
pressure terhadap perilaku disfungsional auditor yang dimediasi oleh skeptisisme profesional auditor.

Theory of attitude change adalah teori yang memprediksi sikap dan perilaku yang terdiri atas berbagai macam teori yang dinaunginya (Siegel dan Marconi, 1989 dalam Mahatma \& Suaryana, 2012), contohnya Dissonance Theories dan Functional Theory. Dissonance theory adalah ketidaksesuaian mendorong seseorang untuk mengeliminasi atau mengurangi ketidaksesuaian tersebut. Sedangkan teori fungsional dari perubahan sikap adalah seorang auditor dapat melakukan tindakan apa saja termasuk penyimpangan perilaku untuk memenuhi kebutuhan akan kesesuaian tuntutan yang diperolehnya (Sadaf et al., 2014).

Auditor merupakan suatu profesi yang sangat penting untuk dikaji, dalam hal ini perilaku disfungsional auditor perlu dihindari sebagai tanggung jawab profesi akuntan dalam melaksanakan pemeriksaan audit, sehingga dalam hal ini skeptisisme professional perlu dilaksanakan walaupun dengan adanya time budget pressure untuk menghindari terjadinya perilaku disfungsional auditor untuk meningkatkan hasil laporan audit (Marisa, 2016).

Adapun rumusan masalah dalam penelitian ini adalah 1) Bagaimana pengaruh time budget pressure pada perilaku disfungsional auditor dikantor Akuntan Publik di Bali? 2) Bagaimana pengaruh time budget pressure pada skeptisisme professional auditor dikantor Akuntan Publik di Bali? 3) Bagaimana pengaruh skeptisisme professional auditor pada perilaku disfungsional auditor dikantor Akuntan Publik di Bali? 4) Bagaimana skeptisisme professional 
Ida Ayu Made Widiantari dan Ida Bagus Putra Astika. Pengaruh...

memediasi pengaruh time budget pressure pada perilaku disfungsional dikantor Akuntan Publik di Bali?

Menurut Cacioppo et al. (1994) dalam Siti (2013), perubahan sikap (attitude change) mengacu pada modifikasi umum persepsi evaluatif individu atas stimulus atau serangkaian rangsangan. Sehingga, perubahan untuk alasan apapun yang menguntungkan atau tidak menguntungkan dalam diri seseorang secara umum tetap bergantung pada beberapa orang, obyek, atau masalah yang terjadi dalam rubrik perubahan sikap. Tidak termasuk dalam rubrik perubahan sikap yaitu perubahan dalam pengetahuan atau keterampilan (misalnya, dari pendidikan), dan perubahan pada perilaku yang membutuhkan pengawasan atau sanksi dari pihak lain (misalnya, dalam bentuk kepatuhan). Oleh karena itu, perubahan sikap (attitude change) merupakan bentuk spesifik dari pengendalian diri sesorang dan pengendalian sosial yang tidak bergantung pada suatu paksaan.

Cacioppo et al. (1994) dalam Siti (2013) menjelaskan dalam teori ini menyebutkan bahwa dissonance (ketidakseimbangan) terjadi karena dalam diri individu terdapat dua elemen kognisi yang saling bertentangan. Elemen bertentangan yaitu pengetahuan, pendapat atau keyakinan. Apabila individu menghadapi suatu stimulus atau objek, dan stimulus tersebut menimbulkan pendapat atau keyakinan yang berbeda di dalam individu itu sendiri. Penyeleseian konflik ini adalah penyesuaian diri secara kognitif. Dengan penyesuaian diri ini maka akan terjadi keseimbangan kembali dan keberhasilan yang ditunjukan itu dengan tercapainya keseimbangan kembali menunjukan adanya perubahan sikap dan akhirnya akan terjadi perubahan perilaku merujuk ke perilaku disfungsional 
(Notoatmjdo, 2007:112). Dalam teori disonansi kognitif ada tiga elemen yang menjadi sorotan, yaitu : 1) Tidak relevan satu sama lain, 2) Konsisten satu sama lain (harmoni), dan 3) Tidak konsisten satu sama lain (disonansi).

Menurut Mulyadi (2002:3) disonansi kognitif adalah ketidaksesuaian yang terjadi antara dua elemen kognitif yang tidak konsisten yang menyebabkan ketidaknyamanan Psikologis serta memotivasi orang untuk berbuat sesuatu agar disonansi itu dapat dikurangi. Istilah disonansi/disonan berkaitan dengan istilah konsonan dimana keduanya mengacu pada hubungan yang ada antara elemen. Elemen-elemen yang dimaksud adalah elemen kognitif.

Auditor adalah seorang yang memiliki kualifikasi tertentu dalam melakukan audit atas laporan keuangan dan kegiatan suatu perusahaan atau organisasi. Menurut Mulyadi (2002:68) auditor dapat dibedakan menjadi tiga jenis, antara lain 1) Auditor pemerintah adalah auditor yang bertugas melakukan audit atas keuangan Negara pada instansi-instansi pemerintah. Di Indonesia audit ini dilakukan oleh Badan Pemeriksaan Keuangan (BPK). 2) Eksternal auditor atau akuntan public adalah seorang praktisi dan gelar professional yang diberikan kepada akuntan di Indonesia yang telah mendapat izin untuk memberikan jasa audit umum dan review atas laporan keuangan, audit kinerja, dan audit khusus serta jasa nonassurancce seperti jasa konsultasi, jasa kompilasi, jasa perpajakan. Jasa-jasa yang ditawarkan oleh akuntan publik ini dilakukan pada perusahaan terbuka, yaitu perusahaan yang go public, perusahaan-perusahaan besar dan juga perusahaan kecil serta organisasi yang tidak bertujuan mencari laba. Praktik akuntan publik harus dilakukan melalui suatu Kantor Akuntan Publik (KAP). 3) 
Ida Ayu Made Widiantari dan Ida Bagus Putra Astika. Pengaruh...

Internal auditor merupakan auditor yang bekerja suatu perusahaan dan oleh karenanya berstatus sebagai pegawai pada perusahaan tersebut. Tugas utamanya ditujukan untuk membantu manajemen perusahaan tempat dimana ia bekerja.

Perilaku disfungsional audit dapat memberikan pengaruh pada kualitas audit, baik secara langsung maupun tidak langsung. Perilaku yang mempunyai pengaruh langsung diantaranya adalah premature sign off dan altering atau replacing audit procedures (Donnelly dkk., 2003; Fikri, 2015). Premature sign off atau penghentian prematur atas prosedur audit berkaitan dengan penghentian prosedur audit secara dini yang dilakukan oleh seorang auditor dalam melakukan penugasan. Sementara itu, altering atau replacing audit procedures berkaitan dengan penggantian prosedur audit yang telah ditetapkan untuk melakukan audit dilapangan.

Sementara itu tipe disfungsional perilaku auditor yang dikemukakan oleh Rhode (1978) dalam Desi dan Armanto (2015), mengatakan bahwa tekanan anggaran waktu berpotensi menyebabkan perilaku penurunan kualitas audit. Time budget pressure adalah suatu keadaan ketika auditor dituntut untuk melakukan efisiensi terhadap anggaran waktu yang telah disusun (Mahatma dan Suaryana, 2016). Anggaran waktu (time budget) disusun digunakan untuk memprediksi waktu yang dibutuhkan setiap tahap pelaksanaan program audit untuk berbagai tingkat auditor (Mohd et al., 2017).

Dalam standar umum ketiga dalam PSA No. 04, SA Seksi 230 SPAP (2011) dikatakan "dalam pelaksanaan audit dan penyusunan laporannya, auditor wajib menggunakan kemahiran profesionalnya dengan cermat dan saksama”, yang 
juga dapat disebut sebagai due professional care, yang termasuk di dalamnya sikap skeptisisme profesional yang dituntut dari auditor dengan cermat dan saksama dalam penugasan auditnya.

Dalam SA Seksi 230 SPAP (2011), skeptisme profesional diartikan sebagai sikap yang mencakup pikiran yang selalu mempertanyakan dan melakukan evaluasi secara kritis atas bukti audit. Berdasarkan IAASB (2010), skeptisisme profesional pada dasarnya adalah pola pikir. Sebuah pola pikir skeptis mendorong perilaku auditor untuk menerapkan pendekatan mempertanyakan ketika mempertimbangkan informasi dan untuk membentuk kesimpulan. Skeptisisme profesional juga termasuk menjadi waspada, misalnya, bukti audit yang bertentangan dengan bukti audit lain yang diperoleh, atau informasi yang perlu mempertanyakan keandalan dokumen atau tanggapan terhadap pertanyaan yang akan digunakan sebagai bukti audit.

Marisa (2016) menyatakan bahwa time budget pressure dapat mempengaruhi terjadinya perilaku disfungsional auditor. Shaun et al. (2008) menyatakan hal yang sama dimana time budget pressure secara positif mempengaruhi tindakan perilaku disfungsional auditor. Desi dan Armanto (2015) dalam penelitiannya membuktikan ada pengaruh positif time budget pressure terhadap perilaku disfungsional auditor dalam melaksanakan audit perusahaan.

Medhat \& Gary (2015) menyatakan bahwa time budget pressure secara langsung berpengaruh terhadap sikap skeptisisme professional auditor. Halil et al. (2010) menyatakan bahwa sikap skeptisisme profesional secara langsung dipengaruhi oleh time budget pressure. Mahatma dan Suaryana (2016) 
Ida Ayu Made Widiantari dan Ida Bagus Putra Astika. Pengaruh...

menyatakan hal yang sama dimana time budget pressure secara langsung berpengaruh terhadap sikap skeptisisme professional auditor.

Indri dan Sukartha (2017) menyatakan bahwa skeptisisme profesional berpengaruh terhadap perilaku disfungsional auditor. Halil et al. (2010) menyatakan bahwa skeptisisme profesional secara tidak langsung mempengaruhi perilaku disfungsional auditor. Medhat \& Gary (2015) menyatakan hal yang sama dimana skeptisisme professional berpengaruh secara negatif pada perilaku disfungsional auditor.

Berdasarkan paparan teori serta penelitian terdahulu dapat disusun hipotesis sebagai jawaban sementara pada penelitian ini sebagai berikut:

$\mathrm{H}_{1} \quad$ : time budget pressure berpengaruh positif pada perilaku disfungsional auditor

$\mathrm{H}_{2} \quad$ : time budget pressure berpengaruh negatif pada skeptisisme profesional auditor.

$\mathrm{H}_{3} \quad$ : Skeptisisme profesional auditor berpengaruh negatif pada perilaku disfungsional auditor.

\section{METODE PENELITIAN}

Berdasarkan jenisnya (Sugiyono, 2014: 13), data dapat dibagi menjadi dua yaitu Data kuantitatif merupakan data yang berbentuk angka-angka atau data-data kualitatif yang diangkakan (Sugiyono, 2014:14). Data kualitatif dalam penelitian ini berupa jumlah auditor yang bekerja pada masing-masing kantor akuntan publik dan hasil hasil kuesioner yang merupakan jawaban responden yang diukur dengan skala Likert. Data kualitatif merupakan data yang dinyatakan dalam bentuk kata, kalimat, dan gambar (Sugiyono, 2014:14). Data kualitatif dalam penelitian ini adalah nama kantor akuntan public yang terdaftar pada Directory kantor Akuntan 
Publik wilayah Bali, gambaran umum kantor akuntan publik, dan struktur organisasi kantor akuntan publik.

Berdasarkan sumbernya (Wirawan, 2002: 6), data dibagi menjadi dua, yaitu Data Primer, yaitu data yang di kumpulkan dan diolah sendiri oleh suatu badan atau individu secara langsung dari objeknya. Data primer dalam penelitian ini yaitu jawaban-jawaban yang diberikan oleh responden atas pertanyaanpertanyaan dalam kuesioner yang berhubungan dengan penelitian. Data Skunder, yaitu data yang diperoleh dalam bentuk sudah jadi, sudah dikumpulkan oleh pihak lain. Data sekunder dalam penelitian ini adalah data yang dikumpulkan dari sumber lain yaitu daftar Kantor Akuntan Publik (KAP) yang terdapat di Bali.

Variabel merupakan suatu sifat yang dapat memiliki berbagai macam nilai. Berdasarkan hipotesis yang telah dikemukakan, maka variabel yang akan dianalisis adalah Variabel yang menjadi mediasi dalam penelitian ini adalah skeptisisme professional (M). Variabel Bebas/Independent variable (X), yaitu variabel yang mempengaruhi atau menjadi timbulnya variabel terikat (Sugiyono, 2014: 31). Variabel bebas dalam penelitian ini adalah time budget pressure (X). Variabel Terikat/dependent variable (Y), yaitu variabel yang dipengaruhi atau menjadi akibat adanya variabel bebas (Sugiyono, 2014: 33). Variabel terikat dalam penelitian ini adalah perilaku disfungsional auditor (Y).

Populasi adalah wilayah generalisasi yang terdiri atas objek atau subjek yang mempunyai kualitas dan karakteristik tertentu yang ditetapkan oleh peneliti untuk dipelajari dan kemudian ditarik kesimpulannya. (Sugiyono,2016:90) Populasi dalam penelitian ini adalah seluruhauditor yang bekerja pada Kantor 
Akuntan Publik di Bali yang berjumlah sebanyak 70 orang. Tabel 1. Berikut menampilkan jumlah populasi dalam penelitian ini.

Tabel 1.

Jumlah Populasi Penelitian

\begin{tabular}{clc}
\hline No. & \multicolumn{1}{c}{ Nama Kantor Akuntan Publik } & $\begin{array}{c}\text { Jumlah Auditor } \\
\text { (orang) }\end{array}$ \\
\hline 1. & KAP I Wayan Ramantha & 10 \\
2. & KAP Johan Malonda Mustika \& Rekan (Cab) & 10 \\
3. & KAP K. Gunarsa & 3 \\
4. & KAP Drs. Ketut Budiartha, M.Si & 6 \\
5. & KAP Drs. Sri Marmo Djogokarsono \& Rekan & 16 \\
6. & KAP Drs. Wayan Sunasdyana & 5 \\
7. & KAP Drs. Ketut Muliartha R.M \& Rekan & 9 \\
8. & KAP Arnaya \& Darmayasa & 10 \\
9. & KAP Budhananda Munidewi & 1 \\
Total & & 70 \\
\hline
\end{tabular}

Sumber: Hasil konfirmasi survey, 2017

Sampel adalah bagian dari jumlah dan karakteristik yang dimiliki oleh populasi tersebut. Jumlah sampel yang akan dilibatkan dalam penelitian ini adalah sebanyak 70 responden yaitu keseluruhan auditor yang bekerja di Kantor Akuntan Publik di Bali dengan menggunakan metode sensus, dimana teknik penentuan sampel ini menggunakan semua anggota populasi sebagai sampel (Sugiyono, 2016: 68).

Observasi adalah pengumpulan data dengan cara mengadakan pengamatan langsung ke perusahaan terhadap obyek yang diteliti, seperti aktivitas auditor yang bekerja pada Kantor Akuntan Publik di Bali. Wawancara adalah cara pengumpulan data yang dilakukan dengan bertanya langsung dengan auditorauditor yang bekerja pada Kantor Akuntan Publik di Bali. Dalam penelitian ini, data yang diperoleh dengan teknik wawancara meliputi data jumlah auditor yang bekerja pada Kantor Akuntan Publik di Bali. Teknik pengumpulan data yang dilakukan dengan cara memberikan seperangkat pertanyaan atau pernyataan 
tertulis kepada responden untuk dijawab (Sugiyono, 2016: 135). Kuesioner tersebut akan diberikan kepada responden dengan diantar langsung oleh peneliti. Untuk masing-masing pernyataan dalam kuesioner, diberikan skor 1-5 berdasarkan skala likert.

Teknik analisis data yang digunakan dalam penelitian ini adalah teknik analisis jalur (path analysis). Analisis jalur merupakan perluasan dari analisis regresi linier berganda, untuk menaksir hubungan kausalitas antar variabel yang berjenjangberdasarkan teori (Utama, 2009:135).

\section{HASIL DAN PEMBAHASAN}

Data dikumpulkan dengan menyebar kuesioner ke tujuh kantor Akuntan Publik. Ringkasan pengiriman dan pengembalian kuesioner dapat dilihat pada Tabel 2.

\section{Tabel 2.}

\section{Rincian Pengiriman dan Pengembalian Kuesioner}

\begin{tabular}{lcc}
\hline \multicolumn{1}{c}{ Kuesioner } & Jumlah & Persentase \\
\hline Kuesioner yang disebar & 70 & $100 \%$ \\
Kuesioner yang tidak kembali & 18 & $25,7 \%$ \\
Kuesioner yang kembali & 52 & $74,3 \%$ \\
Kuesioner yang digugurkan & 0 & $0 \%$ \\
Kuesioner yang digunakan & 52 & $74,3 \%$ \\
Tingkat pengembalian kuisioner & $52 / 70 \times 100 \%=$ & $74,3 \%$ \\
Kuisioner yang digunakan & $52 / 70 \times 100 \%=$ & $74,3 \%$ \\
\hline Sumber: Data diolah, 2017 & &
\end{tabular}

Tabel 2. menunjukan bahwa kuesioner yang disebar ke responden sebanyak 70 kuesioner dan yang terkumpul sebanyak 52. Terdapat 18 kueisoner yang tidak kembali, tidak terdapat kuesioner yang digugurkan, sehingga secara keseluruhan jumlah kuesioner yang layak digunakan untuk dianalisis sebanyak 52 kuesioner. 
Ida Ayu Made Widiantari dan Ida Bagus Putra Astika. Pengaruh...

Karakteristik responden penelitian ini merupakan profil dari 52 responden yang berpartisipasi dalam pengisian kuesioner. Karakteristik responden penelitian meliputi jenis kelamin, jenjang pendidikan dan lama bekerja, Karakteristik responden dapat dilihat pada Tabel 3., Tabel 4., dan Tabel 5.

Tabel 3. Karakteristik Responden Berdasarkan Jenis Kelamin

\begin{tabular}{ccc}
\hline Jenis Kelamin & Jumlah (Orang) & Persentase $(\boldsymbol{\%})$ \\
\hline Laki-Laki & 38 & 73,1 \\
Perempuan & 14 & 26,9 \\
Total & 52 & 100 \\
\hline Sumber: & Data Diolah, 2017 &
\end{tabular}

Tabel 3. menunjukan proporsi auditor laki-laki dan perempuan berdasarkan jenis kelamin. Dapat diketahui jumlah auditor laki-laki sebanyak 40 orang responden $(73,1 \%)$ dan auditor perempuan sebanyak 14 orang responden (26,9\%). Ini menandakan bahwa auditor laki-laki lebih teliti dalam bekerja dan berani mengambil risiko tanpa memperdulikan tekanan dari pihak-pihak tertentu.

Tabel 4.

Karakteristik Responden Berdasarkan Jenjang Pendidikan

\begin{tabular}{ccc}
\hline Pendidikan Terakhir & Jumlah (Orang) & Persentase (\%) \\
\hline Diploma 3 & 4 & 7,7 \\
S1 & 36 & 69,2 \\
S2 & 12 & 23,1 \\
Total & 52 & 100 \\
\hline Sumber: Data diolah, 2017 & &
\end{tabular}

Tabel 4. berfungsi untuk mengetahui jenjang pendidikan yang dimiliki responden. Responden yang memiliki tingkat pendidikan Diploma sebanyak 4 orang $(7,7 \%)$, S1 sebanyak 36 orang $(69,2 \%)$ dan S2 sebanyak 12 orang $(23,1 \%)$. Ini menandakan bahwa semakin baik tingkat pendidikan seorang auditor dapat 
menunjukkan tingkat kinerjanya dalam melakukan audit dengan kualitas yang lebih baik serta pengetahuan yang lebih luas.

Tabel 5.

Karakteristik Responden Berdasarkan Lama Bekerja

\begin{tabular}{|c|c|c|}
\hline $\begin{array}{c}\text { Pengalaman Bergabung Dalam Tim } \\
\text { Audit }\end{array}$ & Jumlah (Orang) & Persentase $(\%)$ \\
\hline Kurang dari 5 Tahun & 21 & 40,3 \\
\hline $5 \mathrm{~s} / \mathrm{d} 10$ tahun & 31 & 59,7 \\
\hline Total & 52 & 100 \\
\hline
\end{tabular}

Sumber: Data diolah, 2017

Tabel 5. berfungsi untuk mengetahui lama responden bergabung dalam suatu tim audit. Dapat dilihat responden yang tergabung dalam tim audit kurang dari atau sama dengan lima tahun sebanyak 21 orang (40,3\%). Responden yang tergabung dalam tim audit lebih dari lima tahun sampai 10 tahun sebanyak 31 orang $(59,7 \%)$. Berdasarkan data tersebut bisa kita lihat seluruh responden sudah pernah tergabung dalam tim audit. Hal ini menunjukan bahwa responden yang digunakan dalam penelitian ini layak digunakan dan menunjukkan data yang valid, karena dengan bergabungnnya dalam tim audit tentunya akan menambah atau meningkatkan standar kinerja Auditor internal tersebut.

Statistik deskriptif menyajikan informasi mengenai karakteristik variabelvariabel penelitian yaitu jumlah amatan, nilai minimum, nilai maksimum, nilai mean, dan standar deviasi. Untuk mengukur nilai sentral dari distribusi data dapat dilakukan dengan pengukuran rata-rata (mean) sedangkan standar deviasi merupakan perbedaan nilai data yang diteliti dengan nilai rata-ratanya. Hasil statistik deskriptif dapat dilihat pada Tabel 6. 
Tabel 6.

Hasil Statistik Deskriptif

\begin{tabular}{lccccc}
\hline \multicolumn{1}{c}{ Variabel } & N & Min. & Max. & Mean & $\begin{array}{c}\text { Std. } \\
\text { Deviasi }\end{array}$ \\
\hline Time budget pressure & 52 & 13 & 20 & 17,00 & 2,369 \\
Skeptisisme profesional & 52 & 15 & 24 & 20,17 & 2,895 \\
Perilaku disfungsional auditor & 52 & 7 & 12 & 10,19 & 1,704 \\
\hline
\end{tabular}

Sumber: Data diolah, 2017

Tabel 6. dapat dilihat bahwa variabel time budget pressure $(\mathrm{X})$ memiliki nilai minimum sebesar 13 , nilai maksimum sebesar 20 , mean sebesar 17,00 , dan standar deviasi sebesar 2,369. Ini berarti bahwa terjadi perbedaan nilai time budget pressure yang diteliti terhadap nilai rata-ratanya sebesar 2,369.

Variabel skeptisisme profesional (M) memiliki nilai minimum sebesar 15, nilai maksimum sebesar 24, mean sebesar 20,17, dan standar deviasi sebesar 2,895. Ini berarti bahwa terjadi perbedaan nilai skeptisisme profesional yang diteliti terhadap nilai rata-ratanya sebesar 2,895.

Variabel perilaku disfungsional auditor (Y) memiliki nilai minimum sebesar 7 , nilai maksimum sebesar 12 , mean sebesar 10,19 , dan standar deviasi sebesar 1,704. Ini berarti bahwa terjadi perbedaan nilai perilaku disfungsional auditor yang diteliti terhadap nilai rata-ratanya sebesar 1,704 .

Pengujian validitas tiap butir digunakan analisis item yaitu mengkorelasikan skor tiap item dengan skor total item. Jika korelasi item terhadap skor total lebih besar dari $\mathrm{r}$ kritis $(0,30)$ maka instrumen dikatakan valid yang disajikan pada Tabel 7. berikut. 
Tabel 7.

Hasil Uji Validitas

\begin{tabular}{ccc}
\hline Variabel & Instrumen & Pearson Correlation \\
\hline Time budget pressure $(\mathrm{X})$ & $\mathrm{X}_{1.1}$ & 0,741 \\
$\mathrm{X}_{1.2}$ & $\mathrm{X}_{1.3}$ & 0,918 \\
& $\mathrm{X}_{1.4}$ & 0,823 \\
& $\mathrm{X}_{1.5}$ & 0,813 \\
Skeptisisme profesional(M) & $\mathrm{M}_{.1}$ & 0,657 \\
& $\mathrm{M}_{.2}$ & 0,648 \\
& $\mathrm{M}_{.3}$ & 0,834 \\
& $\mathrm{M}_{.4}$ & 0,774 \\
& $\mathrm{M}_{.5}$ & 0,863 \\
& $\mathrm{M}_{.6}$ & 0,829 \\
& $\mathrm{Y}_{1}$ & 0,674 \\
& $\mathrm{Y}_{2}$ & 0,859 \\
& $\mathrm{Y}_{3}$ & 0,843 \\
\hline
\end{tabular}

Sumber: Data diolah, 2017

Tabel 7. dibawah terlihat variabel time budget pressure memiliki pearson correlation dari $0,657-0,918(>0,30)$, hal ini berarti bahwa pernyataan tersebut valid. Variabel skeptisisme profesional memiliki pearson correlation dari 0,648$0,834(>0,30)$, hal ini berarti bahwa pernyataan tersebut juga valid. Variabel perilaku disfungsional auditor memiliki pearson correlation dari $0,752-0,859$ (> 0,30), hal ini berarti bahwa pernyataan dalam kuesioner adalah valid.

Pengujian reliabilitas dalam penelitian ini menggunakan metode Cronbach's Alpha. Instrumen dikatakan reliabel untuk mengukur variabel bila berada di atas angka 0,60. Hasil pengujian reliabilitas instrumen dapat dilihat pada Tabel 8 di bawah ini: 
Tabel 8.

Hasil Uji Reliabilitas

\begin{tabular}{lc}
\hline \multicolumn{1}{c}{ Variabel } & Cronbach's Alpha \\
\hline Time budget pressure (X) & 0,837 \\
Skeptisisme professional (M) & 0,858 \\
Perilaku disfungsional auditor (Y) & 0,753 \\
\hline Sumber: Data diolah, 2017 &
\end{tabular}

Tabel 8. menjelaskan bahwa nilai alpha di hitung masing-masing variabel lebih besar dari $\mathrm{R}$ alpha tabel yaitu 0,60 sehingga dapat disimpulkan bahwa pernyataan dalam kuesioner tersebut reliabel.

Uji normalitas ini dilakukan untuk menguji apakah dalam sebuah model regresi (variabel dependen dan variabel independen ataupun keduanya) memiliki distribusi normal atau tidak. Pengujian normalitas nilai residual dalam penelitian ini dilakukan dengan menggunakan metode Kolmogorov-Smirnov. Data dikatakan berdistribusi normal jika taraf signifikansi lebih besar dari 0,05. Dari Lampiran 6 diketahui nilai signifikansi sebesar $0,505(0,505>0,05)$. Hal ini berarti model regresi berdistribusi normal.

\section{Tabel 9.}

Hasil Uji Asumsi Klasik

\begin{tabular}{lcc}
\hline \multicolumn{1}{c}{ Uji Asumsi Klasik } & Hasil Uji & Keterangan \\
\hline Uji Normalitas & $\mathrm{p}(0,505)>0,05$ & Berdistribusi normal \\
Uji Multikolinearitas & Tolerance $(0,426) ;(0,426)>$ & \\
& 0,1 & Tidak ada multikolinearitas \\
Uji Heteroskedastisitas & $\mathrm{VIF}(2,348) ;(2,348)<10$ & \\
& $\mathrm{p}(0,468) ;(0,683)$ & Tidak terjadi \\
& & heteroskedastisitas \\
\hline
\end{tabular}

Sumber: Data diolah, 2017

Output hasil SPSS hasil pengujian pengaruh variabel time budget pressure (X) terhadap perilaku disfungsional auditor (Y) disajikan pada lampiran 7, beberapa hasil olahan statistik yang penting untuk pengujian hipotesis dapat diuraikan seperti pada Tabel 10 . 
Tabel 10.

Hasil Analisis Jalur Pengaruh Time Budget Pressure Terhadap Perilaku Disfungsional Auditor

\begin{tabular}{lcccc}
\hline Model & & $\begin{array}{c}\text { Standardized } \\
\text { Coefficients } \\
\text { Beta }\end{array}$ & T & Sig. \\
\hline (Constant) & & 6.119 & 2.267 & 0.028 \\
Time BP & $: 0,696$ & 0.428 & 4.654 & 0.000 \\
$\mathrm{R}^{2}$ & & & \\
F Statistik & $: 56,221$ & & & \\
Sig.F & $: 0,000$ & & & \\
\hline \multicolumn{1}{c}{ Sumber: Data diolah, 2017} & & &
\end{tabular}

Sumber: Data diolah, 2017

Berdasarkan laporan pada Tabel 10., maka persamaan strukturalnya adalah sebagai berikut:

$$
\mathrm{Y}=0.428 \mathrm{X}+\mathrm{e}_{1}
$$

Time budget pressure berpengaruh positif signifikan terhadap perilaku disfungsional auditordengan nilai standardized coefficientsbeta sebesar 0,428 dan nilai sig t sebesar $0,000<0,05$, oleh karena nilai standardized coefficients beta sebesar 0,428 dengan nilai sig $\mathrm{t}=0,000$ maka $\mathrm{H}_{0}$ ditolak. Hal ini berarti variabel time budget pressure berpengaruh positif dan signifikan secara parsial terhadap perilaku disfungsional auditor pada Kantor Akuntan Publik Di Bali.

Output hasil SPSS hasil pengujian pengaruh variabel time budget pressure $(\mathrm{X})$ terhadap skeptisisme profesional (M) disajikan pada lampiran 5, beberapa hasil olahan statistik yang penting untuk pengujian hipotesis dapat diuraikan seperti pada Tabel 11. 
Tabel 11.

Hasil Analisis Jalur Pengaruh Time Budget Pressure Terhadap Skeptisisme Profesional

\begin{tabular}{llccc}
\hline Model & & $\begin{array}{c}\text { Standardized } \\
\text { Coefficients } \\
\text { Beta }\end{array}$ & T & Sig. \\
\hline (Constant) & & 35.727 & 18.040 & 0.000 \\
Time BP & -0.979 & -8.211 & 0.000 \\
$\mathrm{R}^{2}$ & $: 0,574$ & & & \\
F Statistik & $: 67,416$ & & & \\
Sig.F & $: 0,000$ & & & \\
\hline
\end{tabular}

Sumber: Data diolah, 2017

Berdasarkan laporan pada Tabel 4.12, maka persamaan strukturalnya adalah sebagai berikut:

$$
M=-0.979 X+e_{1}
$$

Berdasarkan Tabel 4.13 diperoleh nilai standar eror sebagai berikut :

$$
\mathrm{Pe}_{\mathrm{i}}=\sqrt{\left(1-R_{1}^{2}\right)}
$$

$\mathrm{Pe}_{1}=\sqrt{\left(1-R_{1}^{2}\right)}=\sqrt{1-0,574}=0,652$

Time budget pressure berpengaruh negatif terhadap skeptisisme profesional dengan nilai standardized coefficients beta sebesar -0,979 dan nilai sig t sebesar $0,000<0,05$, oleh karena nilai standardized coefficients beta sebesar 0,979 dengan nilai sig $\mathrm{t}=0,000$ maka $\mathrm{H}_{0}$ ditolak. Hal ini berarti variabel time budget pressure berpengaruh negatif secara parsial terhadap skeptisisme profesional pada Kantor Akuntan Publik Di Bali.

Output hasil SPSS hasil pengujian pengaruh variabel skeptisisme profesional auditor (M) terhadap perilaku disfungsional auditor (Y) disajikan pada lampiran 5 yang dapat dilihat pada Tabel 12. 
Tabel 12.

Hasil Analisis Jalur Pengaruh Skeptisisme Profesional Auditor Terhadap Perilaku Disfungsional Auditor

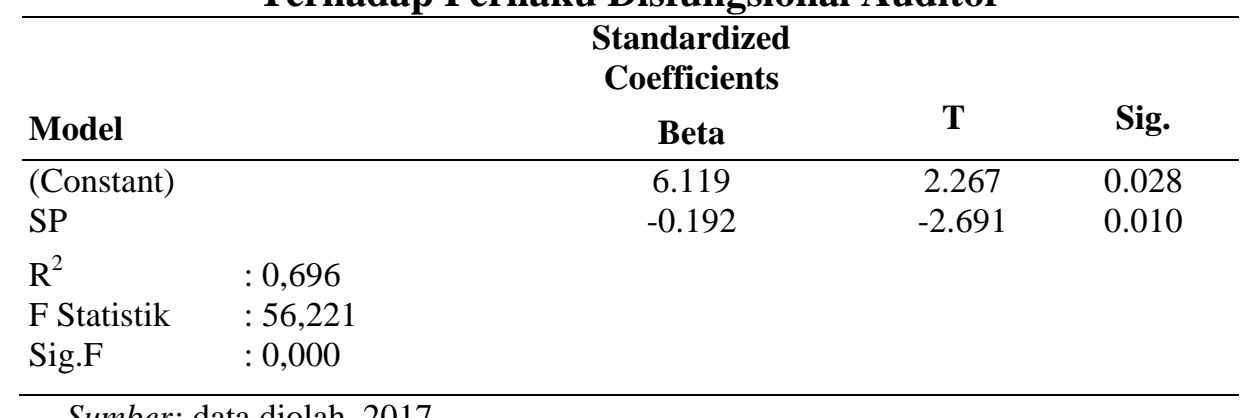

Sumber: data diolah, 2017

Berdasarkan laporan pada Tabel 12., maka persamaan strukturalnya adalah sebagai berikut:

$$
\mathrm{Y}=-0.192 \mathrm{M}+\mathrm{e}_{1}
$$

Skeptisisme profesional auditor berpengaruh negatif terhadap perilaku disfungsional auditor dengan nilai standardized coefficients beta sebesar -0,192 dan nilai sig t sebesar $0,010<0,05$, oleh karena nilai standardized coefficients beta sebesar -0,192 dengan nilai sig $\mathrm{t}=0,010$ maka $\mathrm{H}_{0}$ diterima. Hal ini berarti variabel skeptisisme profesional auditor berpengaruh negatif secara parsial terhadap perilaku disfungsional auditor pada Kantor Akuntan Publik Di Bali.

Pengaruh yang signifikan variabel time budget pressure $(\mathrm{X})$ terhadap perilaku disfungsional auditor $(\mathrm{Y})$ dengan mediasi skeptisisme profesional (M) yang disajikan pada Tabel 13. berikut. 
Tabel 13.

Hasil Analisis Jalur Pengaruh Time Budget Pressure (X) Terhadap Perilaku Disfungsional Auditor (Y) dengan Mediasi Skeptisisme Profesional (M)

\begin{tabular}{lcccc}
\hline Model & & $\begin{array}{c}\text { Standardized } \\
\text { Coefficients } \\
\text { Beta }\end{array}$ & T & Sig. \\
\hline (Constant) & & 6.119 & 2.267 & 0.028 \\
Time BP & 0.428 & 4.654 & 0.000 \\
SP & -0.192 & -2.691 & 0.010 \\
$\mathrm{R}^{2}$ & $: 0,696$ & & & \\
F Statistik & $: 56,221$ & & & \\
Sig.F & $: 0,000$ & & & \\
\hline
\end{tabular}

Sumber: Data diolah, 2017

Berdasarkan laporan pada Tabel 4.14, maka persamaan strukturalnya adalah sebagai berikut:

$$
\mathrm{Y}=0.428 \mathrm{X}-0.192 \mathrm{M}+\mathrm{e}_{2}
$$

Berdasarkan Tabel 4.13 diperoleh nilai standar eror sebagai berikut :

$$
\begin{aligned}
& \mathrm{Pe}_{\mathrm{i}}=\sqrt{\left(1-R_{1}^{2}\right)} \ldots \ldots . .(2) \\
& \mathrm{Pe}_{2}=\sqrt{\left(1-R_{1}^{2}\right)}=\sqrt{1-0,696}=0,551
\end{aligned}
$$

Time budget pressure berpengaruh positif signifikan terhadap perilaku disfungsional auditor dengan mediasi skeptisisme professional auditor, nilai standardized coefficients beta sebesar 0,428 dan nilai sig t sebesar 0,000 $<0,05$, oleh karena nilai standardized coefficients beta sebesar 0,428 dengan nilai sig $\mathrm{t}=$ 0,000 maka $\mathrm{H}_{0}$ ditolak. Hal ini berarti variabel skeptisisme professional auditor memediasi pengaruh positif time budget pressure terhadap perilaku disfungsional auditor pada Kantor Akuntan Publik Di Bali.

Untuk menguji signifikansi peran mediasi variabel skeptisisme profesional digunakan rumus Sobel. Standar error koefisien a dan b ditulis dengan 
$\mathrm{S}_{\mathrm{a}}$ dan $\mathrm{S}_{\mathrm{b}}$, besarnya standar error tidak langsung (indirect effect) $\mathrm{S}_{\mathrm{ab}}$ dihitung dengan rumus berikut ini:

$S_{\mathrm{ab}}=\sqrt{b^{2} S_{a}^{2}+a^{2} S_{b}^{2}+S_{a}^{2} S_{b}^{2}}$

Keterangan :

$\mathrm{S}_{\mathrm{ab}} \quad=$ besarnya standar error tidak langsung

$\mathrm{S}_{\mathrm{a}} \quad=$ standar error koefisien a

$\mathrm{Sb}=$ standar error koefisien $\mathrm{b}$

a $\quad$ = jalur $\mathrm{X}$ terhadap $\mathrm{M}$

$\mathrm{b} \quad=$ jalur $\mathrm{M}$ terhadap $\mathrm{Y}$

$$
\begin{aligned}
& S_{a b}=\sqrt{\left(0,652^{2}\right) 0,068^{2}+\left(0,551^{2}\right) 0,065^{2}+(0,065)^{2}(0,068)^{2}} \\
& S_{a b}=0,056
\end{aligned}
$$

Untuk menguji signifikansi pengaruh tidak langsung maka menghitung nilai z dari koefisien ab dengan rumus sebagai berikut:

$$
\mathrm{z}=\frac{a b}{S_{a b}}
$$

Keterangan:

$\mathrm{S}_{\mathrm{ab}} \quad=$ besarnya standar error tidak langsung

$\mathrm{ab} \quad=$ jalur $\mathrm{X}$ terhadap $\mathrm{M}$ (a) dengan jalur $\mathrm{M}$ terhadap $\mathrm{Y}(\mathrm{b})$

$$
\begin{aligned}
& z=\frac{(0,652)(0,551)}{0,056} \\
& z=6,415
\end{aligned}
$$

Dari hasil perhitungan didapatkan perbandingan nilai z hitung sebesar 6,415 > z tabel sebesar 0,096, maka Ho ditolak dan Hi diterima. Artinya skeptisisme profesional memediasi pengaruh time budget pressure terhadap perilaku disfungsional auditor pada Kantor Akuntan Publik Di Bali. 
Ida Ayu Made Widiantari dan Ida Bagus Putra Astika. Pengaruh...

\section{SIMPULAN}

Berdasarkan hasil analisis pada pembahasan bab-bab sebelumnya dapat disimpulkan bahwa Time budget pressure berpengaruh positif signifikan terhadap perilaku disfungsional auditor pada Kantor Akuntan Publik di Bali. Hal ini berarti bahwa semakin tinggi time budger pressure semakin baik perilaku disfungsional auditor pada Kantor Akuntan Publik di Bali. Time budget pressure berpengaruh negatif terhadap skeptisisme profesional auditor pada Kantor Akuntan Publik di Bali. Hal ini berarti semakin tinggi time budget pressure semakin rendah skeptisme profesional auditor pada Kantor Akuntan Publik di Bali.

Skeptisisme profesional auditor berpengaruh negatif terhadap perilaku disfungsional auditor pada Kantor Akuntan Publik di Bali. Hal ini berarti semakin tinggi skeptisme profesional auditor semakin rendah perilaku disfungsional auditor pada Kantor Akuntan Publik di Bali.

Skeptisisme profesional auditor memediasi pengaruh positif time budget pressure terhadap perilaku disfungsional auditor pada Kantor Akuntan Publik di Bali. hal ini berarti adanya skeptisisme profesional auditor dalam pengaruh time budget pressure terhada perilaku disfungsional auditor pada Kantor Akuntan Publik di Bali.

Berdasarkan kesimpulan maka saran yang dapat disampaikan adalah hasil penelitian ini diharapkan dapat memberikan kontribusi praktis bagi para praktisi auditing khususnya manajemen KAP agar dapat mempertimbangkan karakteristik personal auditor dalam keputusan menetapkan waktu penugasan audit agar tercapai efesiensi audit tanpa mengurangi efektifitas audit. Hal ini dapat 
dilakukan dengan melakukan review secara terus terhadap kertas kerja auditor untuk mengetahui adanya perilaku disfungsional audit. Begitu juga para auditor sebaiknya memperhatikan pentingnya personal yang baik dalam menjalankan audit. Maraknya kasus korupsi dengan tingkat keterlibatan auditor eksternal maupun internal yang semakin meningkat.

Bagi perusahaan yang menggunakan jasa audit, harus memperhatikan ketepatan dalam pelaporan, meningkatkan pelaksanakan aktivitas penilaian dan pemeriksaan atas kebenaran data dan informasi dari sistem dan pengambilan kebijakan yang tepat, sehingga pengawasan dari auditor dalam pengumpulan bukti untuk mendukung temuan audit dapat menghindari perilaku disfungsional untuk mempertahankan keberlangsungan hidup perusahaan.

Peneliti selanjutnya diharapkan dapat mengambil variabel lainnya selain skeptisisme profesional auditor, time budget pressure dan perilaku disfungsional auditor, seperti integritas, moral reasoning, due professional care dengan menerapkan di lokasi penelitian yang lain seperti perbankan, pemerintahan dan lainnya, serta memperhatikan pada penyebaran kuesioner agar diperbarui penggunaan masa tahun bekerja auditor pada Kantor Akuntan Publik agar hasil kuesioner yang didapat lebih akurat.

\section{REFERENSI}

Andreas. 2016. Interaction Between Time budget pressure and Profesional Comitment Towards Underreporting of Time Behavior. International Journal of Social and Behavioral Sciences. 21 (19): h: $91-98$

Anis Rachma Utary. 2014. Effect of Time budget pressure on Dysfunctional Audit and Audit Quality, Information Technology as Moderator. International Journal IJER. 11(3): h: 689-698 
Desi Hutaminingsih, Armanto Witjaksono. 2015. Pengaruh Pengalaman Kerja, Time budget pressure, dan Kompetensi Terhadap Kualitas Audit (Studi Empiris pada Auditor yang Berada Kantor Akuntan Publik di DKI Jakarta). Jurnal Ekonomi Informasi Akuntasi. 1(1): h: 1-12

Dina Purnamasari, Erna Hernawati. 2013. Pengaruh Etika Auditor, Pengalaman, Pengetahuan dan Perilaku Disfungsional terhadap Kualitas Audit. Jurnal Neo-Bis. 7(2): h: 1-17

Fikri Ismail. 2015. Pengaruh Tipe Kepribadian, Pengalaman dan Penerimaan Perilaku Disfungsional terhadap Audit Judgment. Jurnal Bisnis dan Manajemen. 5(2): h: 263-278

Halil Paino, Zubaidah Ismail, Malcolm Smith. 2010. Dysfunctional Audit Behaviour: An Exploratory Study in Malaysia. Journal of Asian Review of Accounting. 18(2): h: 162-173

Indri Septiani, Ni Made,. Sukartha, I Made. 2017. Pengaruh Kompleksitas Audit dan Skeptisme Profesional Auditor pada Penerimaan Perilaku Disfungsional Audit di Kantor Akuntan Publik di Bali. Jurnal Akuntansi Universitas Udayana. 18(1): h: 471-499

Ikatan Auditor Indonesia. 2001. Standar Profesional Auditor Publik. Jakarta: Salemba Empat.

Ikatan Akuntansi Publik Indonesia. "Kode Etik Profesi Akuntan Publik", Institut Akuntan Publik Indonesia. Jakarta, 2009.

Mahatma Setya Devi, Luh,. Suaryana I G.N.A,. 2016. Time budget pressure Memoderasi Pengaruh Karakteristik Personal Auditor terhadap Penerimaan Perilaku Disfungsional Audit. Jurnal Akuntansi Universitas Udayana. 15(3): h: 1994-2023

Marisa Fitria. 2016. Pengaruh Time budget pressure, Due Profesional Care dan Eika Auditor Terhadap Kualitas Audit dengan Perilaku Disfungsional Auditor sebagai mediator (Study Empiris Pada Kantor Akuntan Publik Di Pekanbaru Dan Medan). Jurnal JOM F-KOM. 3(1): h: 119-132

Medhat Endrawes, Gary S. Monroe. 2015. Professional Scepticism of Auditors: A Cross-Cultural Experiment. International Journal of Accounting and Information Management. 2(5): h: 1-41

Mohd Nazli Mohd Nor, Malcolm Smith, Zubaidah Ismail, Roshaiza Taha. 2017. The Effect of Time budget pressure on Auditors' Behaviour. International Journal of American Scientific Publishers. 23(1): h: 356-360

Mulyadi, 2002. Auditing. Edisi ke-6. Jakarta: Salemba Empat. 
Muslim Al Kautsar. 2016. The Influence of Time budget pressure on Dysfunctional Audit Behaviour. South East Asia Journal of Contemporary Business, Economics and Law. 10(1): h: 2289-1560

Nor Balkish Zakaria, Nurhidayah Yahya, Kalsom Salleh. 2013. Dysfunctional Behavior among Auditors: The Application of Occupational Theory. Journal of Basic and Applied Scientific Research. 3(9): h: 495-503

Notoatmodjo, S. 2007. Promosi Kesehatan dan Ilmu Perilaku. Jakarta : Rineka Cipta

Ongky Hartanto. 2012. Pengaruh Locus of Control, Tekanan Anggaran Waktu, Komitmen Profesional, Terhadap Perilaku Disfungsional Auditor. Jurnal Ekonomi dan Keuangan. 20(4): h: 473 - 490

Pretty Sakta Riny. 2015. Pengaruh Kompleksitas Tugas, Locus of Control, Resiko Kesalahan, Terhadap Penurunan Kualitas Audit dengan Perilaku Disfungsional Auditor sebagai variabel Intervening. Jurnal Fekom. 2(2): h: $1-15$

Rabih Nehme, Abdullah Al Mutawa, Mohammad Jizi. 2016. Dysfunctional Behavior of External Auditors The Collision Of Time Budget anf Time Deadline Evidence From A developing Country. The Journal of Developing Areas. 50(1): h: 374-387

Sadaf Khan, Siti Aisyah binti Panatik and Maisarah binti Saat. 2014. Dysfunctional Audit Behaviour: an Exploratory Study in Pakistan. South East Asia Journal of Contemporary Business, Economics and Law. 3(5): h: 1-11

Surtikanti, Lena Lestary. 2015. Pengaruh Profesionalisme Akuntan Publik dan Perilaku Disfungsional Akuntan Publik Terhadap Kualitas Audit (Stusi Kasus pada Kantor Akuntan Publik di Bandung). Jurnal Akuntansi. pp: 69-80

Siti Kustinah. 2013. The Influence Of Dysfunctional Behavior And Individual Culture On Audit Quality. International Journal of Scientific \& Technology Research. 2(5): h: 118-125

Sugiyono. 2014. Metode Penelitian Bisnis. Bandung: CV. Alfabeta.

Suyana Utama, Made. 2009.“Buku ajar Aplikasi Analisis Kuantitatif. Denpasar:

Fakultas Ekonomi Universitas Udayana. 